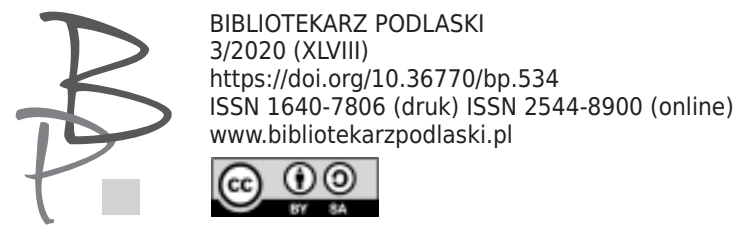

Olexiy Sukhomlynov*

Międzynarodowa Szkoła Ukrainistyki Narodowej Akademii Nauk Ukrainy, Kijów

https://orcid.org/0000-0001-9657-8699

\title{
Польська та українська польськомовна проза XVII століття
}

\section{Polish and Ukrainian Polish prose of the XVII century}

[rec. Svitlana Sukhareva, Polska i ukraińska polskojęzyczna proza

XVII wieku, Łuck: Weża-Druk, 2015, 370 ss.]

Abstract: This article is a review of Svitlana Sukhareva's monograph Polish and Ukrainian Polish-language prose of the 17th century (ukr. «Польська та українська польськомовна проза XVII століття»). The author of the review assesses the results of the research contained in the above-mentioned monograph as necessary for the development of Ukrainian-Polish studies, primarily for the study of Polish prose in the Baroque period, because the mentioned dissertation allows for a comprehensive reflection on the literary process of the PolishUkrainian borderland, which the author of the monograph interprets as Polish-language Ukrainian literature of the 17th century. According to Sukhomlynov, the most important achievement is the isolation of

\footnotetext{
Olexiy Sukhomlynov - prof. dr hab.; pracuje w Międzynarodowej Szkole Ukrainistyki Narodowej Akademii Nauk Ukrainy, a także na Kijowskim Uniwersytecie Narodowym im. Tarasa Szewczenki (Ukraina); autor monografii Кресо-Пограничність Художнього Простору Творів Mapiï Шофер (2016).
} 
dominant concepts of historical and regional progress, namely rhetorical, genealogical, intertextual, mythological, historical and axiological. Besides, it is one of the first detailed analyzes of Polish literature of the Baroque era in Ukrainian philology. The monograph introduces the concept of micro- and mega-species in Baroque literature, which the author of the review considers an innovative contribution to the described research. The author of the review does not see any drawbacks in the dissertation under examination.

Keywords: baroque, Ukrainian-Polish borderland, Polish-language Ukrainian literature of the 17 th century.

Для сучасної полоністики, а разом із тим і для світової медієвістики монографія Світлани Сухарєвої «Польська та українська польськомовна проза XVII століття»є затребуваним дослідженням, що характеризує генологію польської прози добарокової та барокової доби, з урахуванням iii хронологічного та історіографічного аспектів, та дозволяє комплексно осмислити літературний процес польсько-українського пограниччя або, іншими словами, польськомовної української літератури XVII століття з точки зору як історико-регіонального поступу, так і комплексу домінантних концептів, серед яких авторка виділила риторичний, генологічний, інтертекстуальний, міфологічний, історичний, аксіологічний (сакральний і профанний) та деякі інші.

3 огляду на науковий досвід та методологічний підходи до давнього вітчизняного письменства у попередні часи, дослідниця звернула увагу на низку медієвістичних проблем, які до останнього часу знаходилися на периферії наукового дослідження, розглядалися побіжно або взагалі не були розглянуті. До таких проблемно-тематичних «білих плям» української середньовічної літератури відноситься комплекс проблем, пов'язаних із атрибутивними, супутніми та акцидентними критеріями польськомовної прози XVII століття, що стало об'єктом глибокого вивчення та об'єктивного висвітлення у монографії. Важливою заслугою С. Сухарєвої стало також і те, що вона ретельно опрацювала блок польської прози барокової доби, що об’ єктивно укрупнило комплекс проблем, 
окреслених у обраній темі дослідження, й дозволило проаналізувати та поглибити уявлення про тотожність або суголосність літературного поступу в помежівних літературах.

У монографії досліджено, осмислено й виокремлено два самостійні блоки літературознавчих досліджень, які визначино та обгрунтувано в першому розділі «Риторика в структурі польськомовної прози XVII ст.: між Сходом і Заходом», як вивчення двох національних парадигм - польської та української.

Дослідницею обгрунтовано дефініції української та польської літератур, схарактеризовано епічні жанри добарокової та барокової доби, систематизовано проблематику, здійснено герменевтичний аналіз польської прози вказаного періоду, виявлені ознаки барокового концептизму, визначені інтертекстуальні особливості прозових парадигм польської та української польськомовної прози XVII ст., що $є$ найбільш характерними рецепціями суголосних явищ, схожих за словомисленням, образотворенням та світорецепцією $з$ феноменологічним універсумом особливостей як власне польської, так і української польськомовної літератури, зважаючи на поліфункціональність та пограничність цього типу прози, яка існувала паралельно, будучи складовою частиною двох слов'янських літератур.

У монографії С. Сухарєвої залучене широке коло вітчизняного й зарубіжного наукового доробку, який авторка репрезентує як методологічну основу дослідження. Вона використала майже шістсот бібліографічних джерел, серед яких польськомовні стародруки XVII ст., які однаковою мірою стосуються польської та української давніх літератур. Учена запропонувала для аналізу праці Лазаря Барановича, Фабіяна Бірковського, Петра Могили, Якуба Ольшевського, Касіяна Саковича, Шимона Старовольського, Яна Хризостома Паска, Іпатія Потія та ін. Це лише невеликий перелік барокових прозаїків, твори яких було вписано та глибоко проаналізовано в контексті польсько-українського помежів'я.

Про виважену та продуману наукову методологію висвітлення матеріалу свідчать також проблемні дефініції стрижневого об'єкта дослідження, зроблені у самій його назві: риторика, жанри, інтертекст. Це дає можливість констатувати, що дослідження інтертекстуальних кодів польського та українського польськомовного письменства XVII ст., надзвичайно актуальне. Не викликають сумніву обрані об’єкт і предмет дослідження. 
Більшість залучених дослідницею польськомовних текстів українськопольського помежів'я збагачують науковий обіг малодослідженим фактологічним матеріалом, що становить незаперечну літературознавчу та історичну цінність, точніше - безцінність для польської та української літератури й культури.

Книгу С. Сухарєвої можна вважати новаторською з декількох причин. Уперше проповідницькі збірники, листи, мемуари, політичні орації та богословські трактати XVII ст., написані польською мовою, розглянуто як єдину літературну систему, з урахуванням їх жанрової та стильової специфіки. Окрім цього, дослідження враховує гетеромовний чинник формування художньої прози (не менш важливий латинсько- та українськомовний текстовий масив) досліджуваного періоду і звернула увагу на особливості становлення нових жанрових модифікацій, які характерні для епохи бароко, наприклад, політичної брошури, колядної та фацеційної проповіді, апології тощо.

Велике наукове значення для сучасного літературознавства мають другий, третій і четвертий розділи дослідження.

У другому розділі «Генологічні особливості польськомовної прози XVII ст.» подано жанрову таксономію польськомовної прози XVII ст. - від епістолярію, мемуарів та діаріушів до праць проповідницького та ораторського характеру. У межах барокової генології дослідниця запропонувала жанрову парадигму прози польськомовної літератури, вказала на особливості їх жанрової трансформації та модифікації. У роботі зазначається: «В опрацюванні польськомовних прозових творів XVII ст., які попередньо виокремлені нами у формі метажанру, пропонуємо використати традиційно усталені генологічні характеристики з підкресленням їх барокового спрямування. Утім, значиму роль у характеристиці того чи іншого жанру відіграють жанрові архетипи, у яких архаїка перетинається 3 герменевтичними та інтертекстуальними інтерпретаціями окремих творів і мегатексту загалом» (с. 67). Уведені в обіг дослідження поняття мікро- і мегажанрів урізноманітнюють класичний генологічний підхід, відкривають нові аспекти жанрової специфіки прози барокового періоду.

Логічні та чіткі кордони поміж українською та польською парадигмами досліджуваного матеріалу проведено у третьому розділі «Літературні „каміння” та „молоти”: у колі полемічних проблем», оскільки в ньому 
систематизовано польськомовну прозу XVII ст. відповідно до тривимірної проблематики полемічних писань. Мова йде про твори антиосманського, унійного / антиунійного та антитринітарного змісту. Необхідно відзначити, що з рівнем такої систематизації польськомовних письмен у вітчизняному літературознавстві, мабуть не помилюся, якщо скажу, що ми маємо справу вперше. За допомогою риторичного інструментарію вдалося визначити відмінності та спільні риси досліджуваних парадигм із урахуванням сарматського та сарматсько-роксоланського клімату епох. Відзначена також роль шляхти на помежів'ї літератур та вплив козаччини на формування ідейного світу православних письменників. Особливо цінною авторською знахідкою вважаємо апологетичний виклад полемік, представлений у субкультурному вимірі.

Особливу увагу звернено на антитурецький польськомовний доробок Йоаникія Галятовського, Станіслава Конєцпольського, Шимона Старовольського, Марціна Пашковського, Войцєха Кіцького, Кшиштофа Пальчовського, Миколая Хабєльського. У цій прозі концептично обіграно ідеї посполитого рушення, християнського передмур'я, мілітарного союзу та Божої кари за моральні й суспільні провини. У виключно полемічному стилі написані лише вибрані прозові «турчики», проте вони становлять радикальну меншість. Політичні мотиви стосуються промосковської й антимосковської (пропольської, проперської) позицій. За жанровими характеристиками ці твори можна віднести до політичних орацій і брошур, проповідей та полемічних апологій. Значно споріднена 3 антитурецьким полемічним дискурсом проза, присвячена унійній проблематиці.

Особлива увага звернена на українську польськомовну прозу, зазначено ії тісний зв'язок з власне польською літературою. Винятково на межі національних парадигм творили Петро Скарга на останньому етапі своєї діяльності, Теофіл Рутка, Миколай Ціхович, Войцех Кортиський, Станіслав Конєцпольський та ін.

Також у монографії підсумовано результати польськомовної реформаційної та контрреформаційної полеміки. У період раннього й зрілого бароко особливий вплив на розвиток цього типу писань мали такі полемісти, як Миколай Ціхович, Бальтазар Майснер, Йонаш Шліхтинг, Даніель Клементінус, Анджей Вішоватий, Станіслав Любенецький та ін. Реформаційна дискусія набула форм полемічних брошур і памфлетів, 
богословсько-полемічних орацій. Окрім цього авторка виявила контрреформаційні мотиви у творах інших гатунків - проповідях, памфлетах, політичних брошурах, поберестейських богословських та історичних трактатах, «турчиках» тощо.

На підставі аналізу літературних текстів дослідниця доходить до виснову, що полемічна проза становила вагому питому частку польськомовного письменства XVII ст., що свідчило про ії значний вплив на формування суспільної думки, філософських ідеалів та естетичної концепції тогочасної літератури й культури загалом.

Художню вартість опрацьованого польськомовного матеріалу представлено на рівні застосування в текстах східних і західних елементів біблійної герменевтики, багатопланових риторичних прийомів, інтертекстуальних зв'язків діахронічного та синхронічного характеру. Цьому присвячено четвертий, останній розділ монографії: «Інтертекстуальність польськомовної барокової прози: від документалізму до художньої повноти», у якому науково інтерпретовано текстуальний простір досліджуваного матеріалу в контексті концептичних інтертекстових варіацій.

Четвертий розділ має не лише завершальний, а й вершинний характер запропонованого матеріалу, оскільки в ньому встановлені проблемні паралелі між сакральним і профанним, іманентним і трансцендентним, горизонтальними і вертикальними співвідношеннями образів і мотивів, найчастіше почерпнутих зі Святого Письма. Завдяки цій інтерпретації С. В. Сухарєва визначила інтертекстуальні особливості давніх письмен, до яких вона зараховує такі чинники, як «динамічний розвиток ієрофаній як пресупозиції літературних писань і складових елементів концептичних структур; поширення міфологем і свідома сарматизація стилю прозових писань; антитетичність міжтекстових конструкцій; барокове повернення до первинного сенсу символу, заміна метонімічного рівня символіки на метафоричний; розвиток авторського profanum, основаного на потребі вираження національної самобутності та соціальних мотивів; уведення в прозові тексти численних елементів prosimetrum i емблематичного способу відображення світу ідей; продовження риторичної традиції imitatio в єдності $з$ перекладними, латинськомовними та давніми українськомовними видами писань; поява на вітчизняному та польському літературному грунті нових жанрів і жанрових модифікацій барокового характеру 
(«колядних» проповідей, фацецій, анаграм, пасквілів, політичних брошур тощо), трансформація класичних жанрових форм; виникнення й поширення цілісної концептосистеми в інтертекстуальному полі польської та української літератур».

Отже, монографія Світлани Сухаревої «Польська та українська польськомовна проза XVII століття» $€$ вагомим внеском у світову медієвістику та сприятиме подальшому вивченню концептичного виміру художнього слова на різних етапах його становлення, а також, внаслідок врахованого аспекту мовної гетерогенності, слугуватиме грунтовною базою для спільних українсько-польських досліджень літератури, яка знаходиться на пограниччі культур і носить інтегральний характер, який, безсумнівно, свідчить про ії загальноєвропейський рівень.

\section{Bibliografia}

Sukhareva S., Polska i ukraińska polskojęzyczna proza XVII wieku, Łuck: Weża-Druk, 2015. 